\title{
Eco-friendly Fabrication Process of Al-Ti-C Grain Refiner
}

\author{
Hoon $\mathrm{Cho}^{\dagger}$ and Bonghwan Kim \\ Liquid processing \& casting technology R \& D department, Korea Institute of Industrial Technology, Incheon, Korea
}

\begin{abstract}
알루미늄 합금의 미세조직 개량을 위한 목적으로 사용되는 Al-Ti-B 합금계의 미세화제는 재활용 과정에서 붕소(B)의 농축 (Agglomeration) 문제 및 $\mathrm{Zr}, \mathrm{Si}, \mathrm{Cr}$ 등을 함유하는 합금에서 미세화 효과가 급격히 감소하는 Poisoning effect 등이 지적되어 왔다. 최근에는 이를 대체할 수 있는 Al-Ti-C 합금계의 미세화제에 대한 연구가 활발한데 이는 TiC가 용탕 내에서 $\alpha-\mathrm{Al}$ 의 핵생성처로 직접 작용하는 점에 착안한 것이다. 한편, 이들 Al-Ti-B, Al-Ti-C 계의 미세화제는 그 제조공정에서 $\mathrm{K}_{2} \mathrm{TiF}_{6}$ 를 이용함에 따라 불소함유 유해가스를 배출하여 환경 문제를 야기하고, 이를 포집/정화하기 위한 추가설비를 요구하게 된다. 따라서 대기 환 경 오염 및 경제성 측면에서 유리한 미세화제의 친환경 제조기술에 대한 개발이 필요한 시점이다. 본 연구에서는 $\mathrm{K}_{2} \mathrm{TiF}_{6}$ 를 사 용하지 않고 용탕 내의 자발적 반응을 이용하여 환경 및 경제적 측면에서 유리한 Al-Ti-C 미세화제를 개발하고자 하였다. A3003 합금을 대상소재로 하여 개발된 Al-Ti-C 미세화제와 상용 Al-Ti-B 미세화제의 미세화 도달시간 및 fading 발생 등을 비교하였다. 본 연구를 통하여 개발된 Al-8.6Ti-0.025C 미세화제는 상용 Al-Ti-B 미세화제 보다 적은 첨가량에도 유사한 미세화 성능을 나타 내었으며 용탕 유지시간 100 분까지도 fading 이 발생하지 않는 것을 확인하였다.
\end{abstract}

Key words : Grain refinement, Fadingless, Eco-friendly, $\mathrm{TiAl}_{3}, \mathrm{TiC}$.

(Received June 8, 2010 ; Accepted August 14, 2010)

\section{Introduction}

The Al-Ti-B type master alloys have been widely used for grain refinements of both wrought and foundry aluminum alloys [1-2]. Even though Al-Ti-B alloys have the excellent refining efficiency, many efforts has been made to develop alternative one due to both the agglomeration behavior of $\mathrm{B}$ and poisoning effects in $\mathrm{Zr}$, Si, Cr-containing $\mathrm{Al}$ alloys. Recently, Al-Ti-C alloys have been attracted and researched as a promising refiner to achieve fine equiaxed grain structure in many $\mathrm{Al}$ alloys.

Meanwhile, the commercial grain refiners such as Al-Ti-B and Al-Ti-C have been fabricated by reaction of molten Al with $\mathrm{K}_{2} \mathrm{TiF}_{6}$ and graphite powder. This reaction produces the huge amount of environmentally harmful fluoride-containing fumes in the process. The expensive emission control system large enough to handle the periodic high emission rate as well as problems associated with boride agglomeration and poisoning effect in Al-Ti-B refiner have been remained as major concerns. Therefore, the great need for development of eco-friendly fabrication process of efficient grain refiner has been rising in wrought and foundry aluminum industry.

In the present study, it was aimed to develop and suggest an eco-friendly refining process of Al-Ti-C grain refiner and evaluate the refining characteristics as functions of holding time

${ }^{\dagger}$ E-mail : hoony67@kitech.re.kr and amount of addition in a A3003 alloy.

\section{Experimental procedures}

A non-toxic Al-Ti master alloy was melted in a graphite crucible, in which the in-situ formation of $\mathrm{TiC}$ was induced by the reaction of Al-Ti molten metal and carbon from graphite crucible. In order to optimize the reaction time, the carbon content, fraction of $\mathrm{TiC}$ and $\mathrm{TiAl}_{3}$ were measured as a function of holding time in graphite crucible. The prepared molten alloy was gas-atomized to make an Al-Ti-C refiner in powder form. Through these processes as an eco-friendly fabrication process, the final form of the Al-Ti-C refiner was obtained. The chemical composition of the refiner was analyzed and confirmed as Al8.6wt.\%Ti-0.025wt.\%C. The eco-friendly fabricated Al-8.6Ti$0.025 \mathrm{C}$ as well as commercial $\mathrm{Al}-5 \mathrm{Ti}-1 \mathrm{~B}$ grain refiners were added to a molten A3003 alloy in order to evaluate and compare the refining efficiency, fading behavior and mechanical properties. The molten A3003 alloys were poured into a high purity alumina crucible and held at $750^{\circ} \mathrm{C}$ of an isotheral condition in a resistance furnace. The isothermally conditioned melts were directly poured into a cylindrical permanent mold to obtain the quenched microstructure as a function of holding time $(1,5,10,30,60,90,120,150,180$ and 240 minutes $)$ at $750^{\circ} \mathrm{C}$. The chemical compositions of A3003 alloys refined by 
Table 1. Chemical compositions of A3003 alloys refined by the Al8.6Ti-0.025C

\begin{tabular}{cccccccc}
\hline Alloy & $\mathrm{Mn}$ & $\mathrm{Si}$ & $\mathrm{Fe}$ & $\mathrm{Cu}$ & $\mathrm{Zn}$ & $\mathrm{Ti}$ & $\mathrm{Al}$ \\
\hline & 1.9 & 0.4 & 0.51 & 0.2 & 0.12 & 0.049 & \\
$\mathrm{~A} 3003$ & - & - & - & - & - & - & $\mathrm{Bal}$. \\
& 2.1 & 0.5 & 0.58 & 0.3 & 0.19 & 0.15 & \\
\hline
\end{tabular}

the eco-friendly made Al-8.6Ti-0.025C were analyzed and summarized in Table 1.

The grain size of the A3003 alloys refined by the Al-8.6Ti$0.025 \mathrm{C}$ and commercial Al-5Ti-1B refiner were measured by a line intercept method in a polarizing light microscope on polished sample. The representative macrostructures showing the refining efficiency in the whole area of the sample were taken after chemical macro-etching. The hardness of the refined by the Al-8.6Ti-0.025C and unrefined A3003 alloys were compared through the whole area of the sample to verify uniformity of refining ability. The tensile properties were measured as a function of content of the Al-8.6Ti-0.025C refiner to suggest the optimized level of the addition.

\section{Results and discussion}

The Fabrication of the Al-8.6Ti-0.025C grain refiner was carried out by melting of Al-10Ti master alloy in a graphite crucible in order to lead the in-situ formation of TiC phase by the reaction of the molten $\mathrm{Ti}$ and $\mathrm{C}$ from the graphite crucible. As shown in Fig. 1(a), the carbon content of the molten Al-Ti alloy in alumina crucible did not show any appreciable change during the holding period at $750^{\circ} \mathrm{C}$. However, the carbon content of the molten Al-Ti master alloy in graphite crucible increased and reached the saturation point, about $150 \mathrm{ppm}$ of carbon after about $30 \mathrm{~min}$. of the holding time in the crucible. The source of the carbon in the graphite crucible seemed to be from the wall of the crucible in a elevated temperature. And

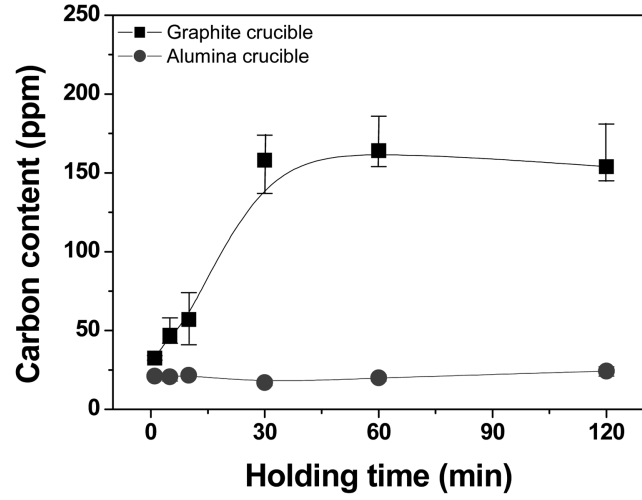

(a) the carbon extracted from the graphite crucible was expected to be involved to the in-situ formation of TiC phase in the molten Al-Ti alloy.

Meanwhile, according to the binary Al-Ti phase diagram, the solubility of titanium in aluminum at $750^{\circ} \mathrm{C}$ is about $0.3 \mathrm{wt} . \%$. Therefore, titanium solute could be expected to be dissolved into molten aluminum as the holding time increases. The titanium solute can be supplied by the decomposition of the preexisting $\mathrm{TiAl}_{3}$ phase in the molten Al-Ti alloy. Therefore, the dissolution of titanium solute into molten aluminum resulted in the decrease of preexisting fraction of $\mathrm{TiAl}_{3}$ phase as shown in Fig. 1(b). On the contrary, the fraction of TiC phase of the molten Al-Ti alloy in the graphite crucible increased as the holding time increased at $750^{\circ} \mathrm{C}$ as shown in Fig. 1(b). It can be suggested that during the holding period, the in-situ reaction between the dissolved solute Ti from $\mathrm{TiAl}_{3}$ and carbon from the graphite crucible produced the $\mathrm{TiC}$ particles consuming gradually the preexisting $\mathrm{TiAl}_{3}$ particles. The reactions in the molten Al-Ti alloy during the holding time in the graphite crucible were summarized in the equation 1 and 2 .

$$
\begin{array}{ll}
\mathrm{TiAl}_{3} \rightarrow \mathrm{Ti}+3 \mathrm{Al} & \text { (Equation 1) } \\
\mathrm{Ti}+\mathrm{C} \rightarrow \mathrm{TiC} & \text { (Equation 2) }
\end{array}
$$

In order to identify and verify the phases formed in the molten $\mathrm{Al}-\mathrm{Ti}$ alloy by the in-situ reaction during the holding period in the graphite crucible, the $\mathrm{Al}-8.6 \mathrm{Ti}-0.025 \mathrm{C}$ powder made by a gas-atomization of the molten Al-Ti alloy was subjected to X-ray diffractometry using $\mathrm{Cu}-\mathrm{K} \alpha$ radiation. Fig. 2 shows the XRD pattern of the fabricated Al-8.6Ti-0.025C powder. The peaks corresponding to $\alpha-\mathrm{Al}, \mathrm{TiC}$ and $\mathrm{TiAl}_{3}$ were detected approving the presence of each phase. Especially, the presence of the $\mathrm{TiC}$ phase indicates the in-situ reactions between the dissolved $\mathrm{Ti}$ solute and carbon from the graphite crucible according to the equations 1 and 2 .

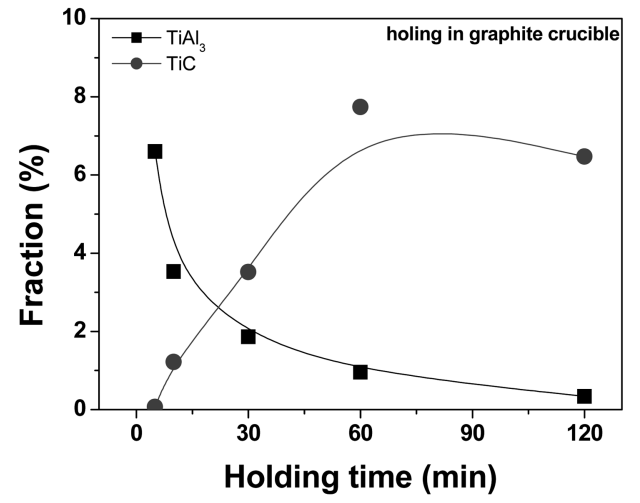

(b)

Fig. 1. The variation of (a) the carbon content and (b) the fractions of $\mathrm{TiC}$ and $\mathrm{TiAl}_{3}$ particle in the molten $\mathrm{Al}$-Ti alloy as a function of the holding time at $750^{\circ} \mathrm{C}$ 


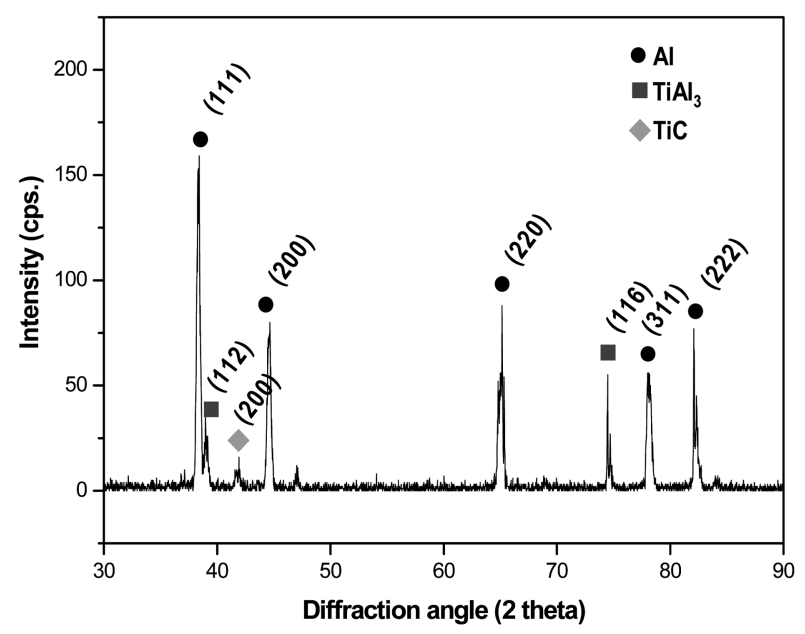

Fig. 2. XRD pattern of the Al-8.6Ti-0.025C powder made by the insitu reaction and a gas-atomization process.

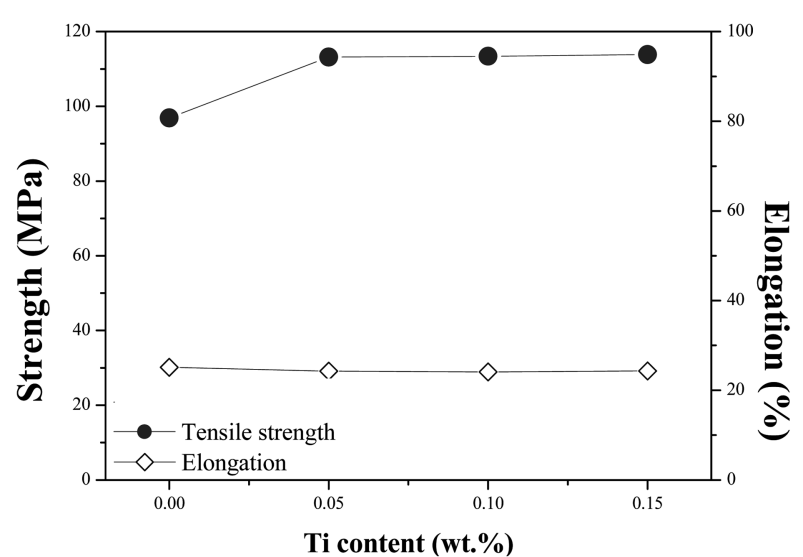

Fig. 3. Tensile strength and elongation of the A3003 alloy refined by the $\mathrm{Al}-8.6 \mathrm{Ti}-0.025 \mathrm{C}$ as a function of the content of Ti.

In order to evaluate the refining ability and behavior, the Al8.6Ti-0.025C powder was added into A3003 alloy. The optimized amount of the addition was decided based on the combined analysis of mechanical properties and microstructure. For the comparison, the recommended amount of the commercial Al-Ti-B refiner was also added into A3003 and characterized together with the Al-8.6Ti-0.025C added specimen.

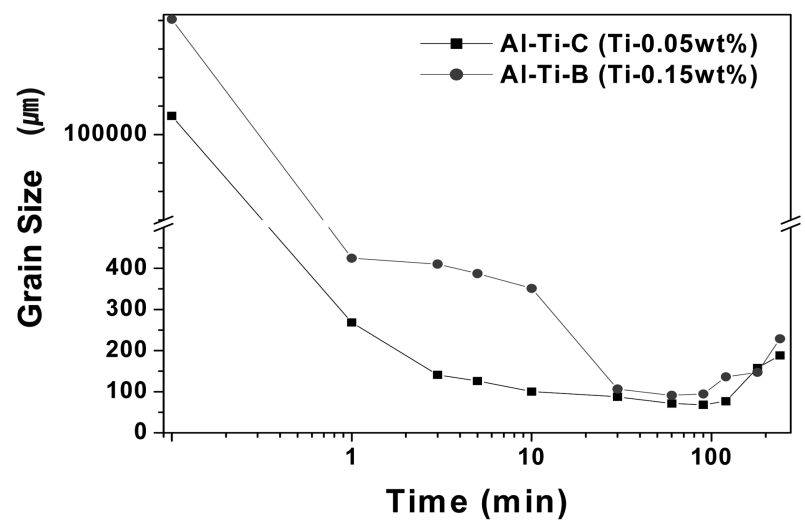

Fig. 4. The grain size of the $\mathrm{A} 3003$ alloys refined by the Al-8.6Ti$0.025 \mathrm{C}$ and the commercial Al-Ti-B as a function of the melttreating time.

The A3003 alloys refined by either the Al-8.6Ti- $0.025 \mathrm{C}$ or the commercial Al-Ti-B were quenched into a cylindrical steel mold after various melt-treating times and analyzed by a combined method of mechanical testing, optical microscopy and image analysis. The tensile properties of the A3003 alloy are shown in Fig. 3 as a function of the content of Ti solute. The tensile strength of the A3003 alloy increased up to the saturation value, about $115 \mathrm{MPa}$ even with $0.05 \mathrm{Ti}$ of a small addition, while the elongation did not show any appreciable change. Therefore, the optimized addition of the Al-Ti-C for the A3003 alloy was decided as the 0.05Ti.

Fig. 4 shows the variation of the grain sizes of the $\mathrm{A} 3003$ alloys refined by either the Al-8.6Ti- $0.025 \mathrm{C}$ or the commercial $\mathrm{Al}-\mathrm{Ti}-\mathrm{B}$ refiner as a function of the melt-treating time in a highpurity alumina crucible. The added amount of the each refiner was converted to the added amount of Ti element and indicated on Fig. 4, respectively. The A3003 alloy refined by the commercial Al-Ti-B shows effective refining ability in a relatively delayed time, about 30min. However, the A3003 alloy refined by the eco-friendly fabricated Al-8.6Ti-0.025C shows almost equivalent refining ability in a relatively short time, a few minutes. It is also worth to mention that the amount of Ti addition by the Al-8.6Ti-0.025C was much smaller than
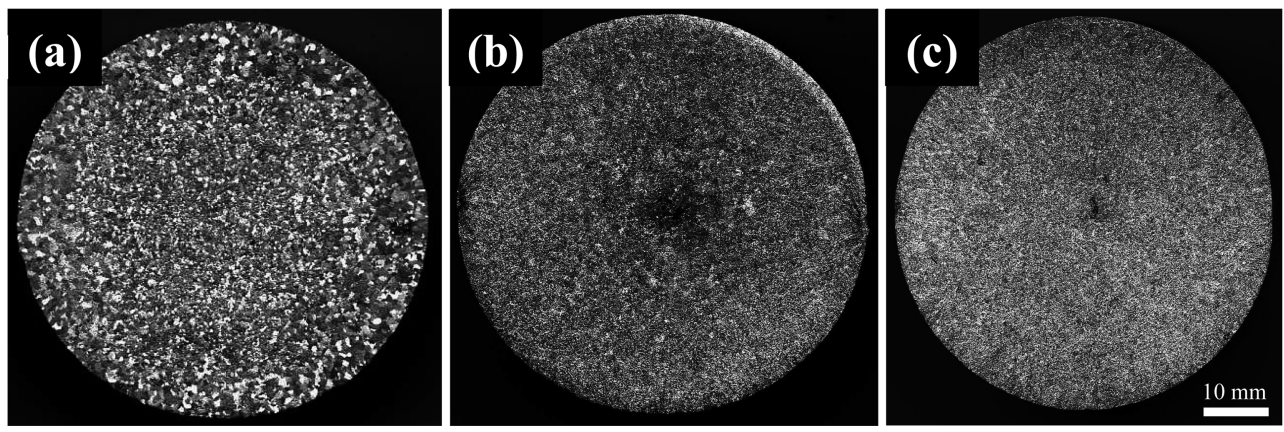

Fig. 5. The representative macrostructures of the A3003 alloys refined by (a) the commercial Al-Ti-B at about 10min. of the melt-treating time and (b)-(c) the Al-8.6Ti-0.025C refiner at about 10 and $120 \mathrm{~min}$., respectively. 
that of the commercial Al-Ti-B refiner, meaning the efficient refining ability of the Al-8.6Ti-0.025C.

Fig. 5 shows the representative macrostructures of the $\mathrm{A} 3003$ alloys refined by (a) the commercial Al-Ti-B at about $10 \mathrm{~min}$. of the melt-treating time and (b)-(c) the Al-8.6Ti-0.025C refiner at about 10 and 120min., respectively. As shown in Figs. 5(a) and (b), the A3003 alloy refined by the Al-8.6Ti-0.025C shows a fine macrostructure compared to that refined by the commercial Al-Ti-B even in the short melt-treating time less than about 10 minute. In the cast of sufficient melt-treating time, both the commercial Al-Ti-B and the Al-8.6Ti-0.025C shows effective refining ability similar to Fig. 5(c).

Both $\mathrm{TiAl}_{3}$ and $\mathrm{TiC}$ particles are known to act as substrates for heterogeneous nucleation of aluminum grains during solidification [3-4]. It is of interest to understand the effects and roles of $\mathrm{TiAl}_{3}$ and $\mathrm{TiC}$ on nucleation. Maxwell and Hellawell have reported that the nucleation of aluminum requires little or no under-cooling in the presence of $\mathrm{TiAl}_{3}$ as compared to $\mathrm{TiC}$ or $\mathrm{TiB}_{2}$, indicating that $\mathrm{TiAl}_{3}$ is able to be suggested as a better nucleant than $\mathrm{TiC}$ or $\mathrm{TiB}_{2}$ for $\alpha-\mathrm{Al}$ [5]. Moreover, $\mathrm{TiAl}_{3}$ is also known to have more number of planes that have a good orientation relationship with $\alpha-\mathrm{Al}$ in comparison to $\mathrm{TiC}$ or $\mathrm{TiB}_{2}$. On the other hands, TiC particle is known to promote direct nucleation of $\alpha-\mathrm{Al}$ when excessive Ti solute contributes as a strong constitutional super-coolant and retards grain growth [6]. Therefore, excessive Ti solute in molten alloy containing carbide particles is able to be expected to have a favorable effect on grain refinement. This could explain why the Al-8.6Ti-0.025C refiner showed effective grain refining ability comparable to the commercial Al-Ti-B refiner. The result of a recent paper wherein Al-8.6Ti-0.025C refiner containing both $\mathrm{TiAl}_{3}$ and TiC exhibits much better effect on refinement of $\alpha-\mathrm{Al}$ than that containing only $\mathrm{TiC}$ [7], revealing the importance of excess $\mathrm{Ti}$ (beyond that combined in $\mathrm{TiC}$ ).

\section{Summary}

An eco-friendly production technique of Al-8.6Ti-0.025C refiner was developed by melting a Al-Ti master alloy in a graphite crucible, in which the potential nucleation site, TiC effectively formed by the spontaneous in-situ reaction between excessive $\mathrm{Ti}$ and carbon from graphite crucible. The A3003 alloy refined by the Al-8.6Ti-0.025C showed effectively refined macrostructure and enhanced mechanical properties comparable to the commercial Al-Ti-B refiner. The effective refinement was achieved in a shorter compare to the melt-treating time commercial Al-Ti-B refiner.

\section{References}

[1] A. Cibula: J. Inst. Met., 76 (1949/1950) 321-360

[2] B. S. Murty, S. A. Kori and M. Charkraborty: International Materials Review, 47 (2002) 3-29

[3] E. L. Grasson and E. F. Emely: "The Solidification of Metals", London: The Iron and Steel Institute (1968)

[4] G. E. Bolling: "Solidification", Materials park, OH (1970)

[5] I. Maxwell and A. Hellwell: Acta Metall., 23 (1975) 229-237.

[6] A. Cibula: J. Inst. Met., 80 (1951/1952) 1-16

[7] Z. Q. Wang, X. F. Liu, S. T. Li, X. F. Bian and J. Y. Zhang: Mater. Sci. Technol., 19 (2003) 1709-1714 